\title{
Characterization of leptospira isolates from animals and humans: phylogenetic analysis identifies the prevalence of intermediate species in India
}

\author{
Vinayagamurthy Balamurugan*, Nidaghatta L Gangadhar, Nagalingam Mohandoss, \\ Sushma Rahim Assadi Thirumalesh, Moushumi Dhar, Rajeswari Shome, Paramanandham Krishnamoorthy, \\ Krishnamsetty Prabhudas and Habibur Rahman
}

\begin{abstract}
In this study, 191 culture isolates were recovered from suspected samples of animals and humans in Ellinghausen McCullough Johnson and Harris (EMJH) medium and assessed for its morphological features by dark field microscopy. Extracted DNA from individual culture was subjected to different PCR assays for identification and characterization of leptospira. Out of 99 positive leptospira cultures, 52 pathogenic leptospira isolates were characterized at species level by using partial RNA polymerase $\beta$-subunit (rpoB) gene sequences. Phylogenetic analysis of the nucleotide sequences revealed that 30,8 , and 14 isolates belong to L. borgpetersenii / L. interrogans, L. kirschneri, and Leptospira intermediate species, respectively. Based on analysis of 99 leptospira isolates, the prevalent Leptospira species were L. borgpetersenii or L. interrogans (30.30\%), L. kirschneri (8\%) and Leptospira intermediate species (14.14\%) in animals and humans. To the best of authors knowledge, this is the first study to use rpoB gene nucleotide sequence based phylogenetic analysis to identify/detect Leptospira intermediate species (L. wolffii) in animals and humans in India. Hence, the prevalence of this species will surely emphasize the importance of consideration of Leptospira intermediate species and formulate a way for further studies especially in understanding the newly emerging Leptospira in animals and humans and to combat the problem associated with the disease conditions.
\end{abstract}

Keywords: Leptospira; Animals; Human; Characterization; Prevalence; Intermediate species

\section{Introduction}

Leptospirosis is an important re-emerging zoonotic disease in tropical and subtropical regions of the world with various animal species acting as carriers. It is considered as an emerging global public health problem (Bharti et al. 2003), caused by different pathogenic species of leptospira and is difficult to control and eradicate in tropical developing countries like India. Hence, early detection of leptospira in the host, prompt treatment as well as creating awareness in the public are the steps

\footnotetext{
*Correspondence: balavirol@gmail.com

Project Directorate on Animal Disease Monitoring and Surveillance

(PD_ADMAS), Hebbal, HA Farm Post, Bengaluru 560 024, Karnataka, India
}

that could be taken to reduce the extent of problem and the economical losses associated with it.

Diagnosis of leptospirosis is usually achieved by serological investigation particularly by microscopic agglutination test (MAT), a gold standard test. The MAT is a well proven, accepted and widely used serological test for the detection of leptospiral antibodies in animals and humans. It is very useful in the demonstration of a four-fold change in antibody titers in paired acute and convalescent sera and is of significant value in diagnosing recent infection. However, in case of animals, getting paired sera is difficult, in such case while testing of single serum in MAT, it is essential to correlate the results with clinical signs of the affected animal. Generally, very high MAT titres 
with a consistent clinical features are conclusive of leptospirosis.

In any particular geographical region, various leptospiral serovars are prevalent and are associated with one or more maintenance host(s) that serves as reservoir of infection. Leptospira spp. are traditionally classified into 29 serogroups and over 300 serovars (Levett 2001). Further, genotypic methods like DNA-DNA hybridization have identified 20 Leptospira spp. to date (Cerqueira and Picardeau 2009). However, antigenically related serovars are classified in two or more different species and a serogroup is often found in several species of leptospira. Serovar identification of isolates are essential to understand the prevalence of leptospira in the epidemiology of this disease, but few laboratories perform Cross Agglutination Absorption Test (CAAT) (Terpstra et al. 1985) and most isolates are therefore not identified at serovar level. Serogroups identified using the MAT have no official taxonomic status, can serve as practical purpose of grouping common antigens together. With the emergence of molecular typing methods, it has become increasingly clearer that the concept of a "serovar" is no longer fully satisfactory as it may fail to define epidemiologically important strains/isolates in an adequate manner (Cerqueira and Picardeau 2009). For example, molecular typing has been shown to give better discrimination of strains of the Grippotyphosa serogroup than serological typing (Steinen et al. 1992; Hartskeerl et al. 2004).

Phylogenetic analysis identifies three major groups of leptospira with few exceptions, based on the pathogenicity such as pathogenic, saprophytic and intermediate strains of unclear pathogenicity (Paster et al. 1991; (Matthias et al. 2008). Genes used to discriminate between species within the genus Leptospira include RNA polymerase $\beta$-subunit (rpoB) (La Scola et al. 2006), DNA gyrase subunit B (gyrB) (Slack et al. 2006) and leptospiral immunoglobulin-like protein $(\operatorname{lig} B)$ (Cerqueira et al. 2009). All the proposed taxonomic markers generate results consistent with those obtained with the $16 \mathrm{~S}$ rRNA sequences in terms of clustering of the strains into three major groups.

The research activities in leptospirosis since inception of Project Directorate on Animal Disease Monitoring and Surveillance (PD_ADMAS) has led to isolation of Leptospira spp. from diverse animals and humans and their maintenance in the repository, development of a simple leptospira staining kit and recording of the leptospiral abortions in bovines and other animal species (Gangadhar and Rajashekar 1998; Gangadhar et al. 2006; 2008). It is imperative to know the circulating Leptospira species/serovars in animals and humans in different geographical locations in order to investigate the prevalence of Leptospira species during monitoring of the leptospirosis. This helps in appropriate use of panel of leptospira serovars in the MAT for providing proper diagnostic without false negative results. Hence, the preliminary study was undertaken to investigate the prevalence of Leptospira species in animals and humans using the archived cultural isolates recovered from suspected samples of animals and humans in different geographical locality of India collected during different periods up to the species level by using rpoB gene- based sequence and phylogenetic analysis.

\section{Materials and methods}

\section{Culture media}

A modified Ellinghausen McCullough Johnson and Harris $(\mathrm{EM}) \mathrm{H})$ liquid medium containing bovine serum albumin fraction V (Ellis 1986) was prepared as per standard bacteriological procedure with $200 \mu \mathrm{g}$ of 5 -fluorouracil per $\mathrm{mL}$ of medium.

\section{Clinical samples}

Clinical samples such as blood, serum, urine and other materials such as kidney, tissues and fluids from aborted fetus collected from suspected animals and humans [most of cases-pyrexia of unknown origin (PUO)] from different geographical locations of India collected either by the ADMAS team or obtained through various organizations such as state animal husbandry laboratories, research institutes and from organized farms which were submitted to the laboratory for leptospira diagnosis. The details of the species from which the samples were collected and the area of origin with brief history of samples and designation of cultural isolates are presented in Table 1 . The majority of clinical materials were from the states of Karnataka, Maharashtra and Gujarat. The animals and human beings from which samples were collected and submitted for diagnosis had clinical signs consistent with leptospira infection especially in humans.

\section{Isolation}

For isolation of leptospira, the serum/blood/urine samples that were collected from the suspected animal were inoculated (1-2 drops) directly to the transport EMJH medium containing $500 \mu \mathrm{g}$ of 5 -fluorouracil per $\mathrm{mL}$ in the field level laboratory or veterinary dispensary or on the site of collection and transported to the laboratory at room temperature. Samples received from the messenger or by post either in the transport medium for isolation or submission of serum/blood samples on ice pack for diagnosis of leptospirosis, upon receipt all the samples were stored at $4^{\circ} \mathrm{C}$ and were further used when required. It was directly inoculated into EMJH medium for isolation. The collected urine, tissue/kidney and fetal fluid/tissues were transported to laboratory either on ice pack or on transport medium, upon receipt the particular pieces of tissues 
Table 1 Details of characterized leptospira isolates from animals and humans

\begin{tabular}{|c|c|c|c|}
\hline $\begin{array}{l}\text { ADMAS } \\
\text { No. }\end{array}$ & $\begin{array}{l}\text { Source of } \\
\text { sample }\end{array}$ & Brief history of samples/specimens, place, year of collection & $\begin{array}{l}\text { GenBank } \\
\text { Acc. No. }\end{array}$ \\
\hline \multicolumn{4}{|c|}{ Karnataka state } \\
\hline 21 & Kidney & Pregnant female rat trapped at military dairy farm, Bangalore, May,1994.\# & $\mathrm{JN} 388643 \bullet$ \\
\hline 121 & Kidney & Female rat trapped in dairy farm at Malleshwaram, Bangalore, August, 1994.\# & JN388654• \\
\hline 421 & Blood/Serum & Repeat breeder cow from University of Agricultural Sciences dairy farm, Bangalore, July,1995.\# & JN388636 \\
\hline 737 & Blood & Referred human case with fever from Bowring and Lady Curzon Hospital, Bangalore, February, 1997.* & HM046992 • \\
\hline 840 & Urine & $\begin{array}{l}\text { Rat from small animal house at Institute of Animal Health and Veterinary Biological, Bangalore, October, } \\
\text { 1997.\# }\end{array}$ & JN388655 \\
\hline 843 & Kidney & $"$ & JN388644 \\
\hline 930 & CSF & 4 1⁄2 years old girl with pyogenic mengitis, Bangalore, March,1998.* & JN388645 \\
\hline 950 & Blood & $\begin{array}{l}\text { Referred human case aged 21years male with fever \& myalgia from Victoria Hospital, Bangalore, April, } \\
\text { 1998.* }\end{array}$ & JN388646 \\
\hline 966 & Urine & $\begin{array}{l}\text { Referred human case aged } 28 \text { years male with fever, jaundice and hematuria from Bangalore Medical } \\
\text { college, June, 1998.* }\end{array}$ & JN388627 \\
\hline 1003 & Blood & Buffalo calf with pyrexia, Hassan, August, 1998,* & JN388656 \\
\hline 1063 & Serum & $\begin{array}{l}\text { Referred human case aged } 30 \text { years male with heptorenal syndrome and leptospira serology positive } \\
\text { from NIMHANS, Bangalore, October,1998.* }\end{array}$ & HM046989 \\
\hline 1147 & Serum & $\begin{array}{l}\text { Referred human case aged } 14 \text { years male with icteric discolouration of eye with heptomegally from St. } \\
\text { Marthas Hospital, Bangalore, July, } 1999 \text {. }\end{array}$ & JN388634 \\
\hline 1178 & Serum & $\begin{array}{l}\text { Referred human case aged } 6 \text { years female with pyrexia for one week from, Bowring and Lady Curzon } \\
\text { Hospital, Bangalore, October, 1999.* }\end{array}$ & HM046997 \\
\hline 1175 & Blood & Bullock with fever from State Breeding and Training Centre, Hassarghatta, October, 1999.* & JN388616 \\
\hline 107 & Kidney & Adult male rat trapped from SPCA(Animal Shelter), Kennel, Bangalore, February, 1995.\# & JN388629 \\
\hline 1190 & Blood & $\begin{array}{l}\text { Alcoholic male aged } 40 \text { years from Gowribidanur with fever for } 8 \text { days (Temperature } 104^{\circ} \mathrm{C} \text { ), August, } \\
\text { 2000.* }\end{array}$ & JN388628 \\
\hline 58 & Blood/ Serum & Female with pyrexia of unknown origin, February, 2010.* & JN388620 \\
\hline G202 & $\begin{array}{l}\text { Foetal } \\
\text { peritoneal fluid }\end{array}$ & Aborted foetus from cow with fever, Kengeri, March, 2007.\# & $J N 388621 \bullet$ \\
\hline G229 & $\begin{array}{l}\text { Foetal heart } \\
\text { blood }\end{array}$ & Aborted foetus from cow with fever, Devanahalli, June, 2007.\# & JN388622 \\
\hline 1345 & Blood & HF cross breed cow with pyrexia and diahhroea, Hosodi, Shimoga, September,2001.\# & HM046993• \\
\hline 1332 & Urine & Urine from the bladder of rat tapped from Veterinary Hospital, Husudi area, Shimoga, September, 2001.\# & JN388633 \\
\hline 1590 & Serum/Blood & Repeat breeder cow with pyrexia from Veterinary Hospital, Mysore Road Bangalore, March, 2004.* & HM046994• \\
\hline 3233 & Blood & $\begin{array}{l}\text { Referred human case of adult male with weakness of the left side body for } 15 \text { days without pyrexia from } \\
\text { KIMS Hospital, Bangalore, March, 2007.* }\end{array}$ & JN388652 \\
\hline 3647 & Heart Blood & Rat trapped at Poultry farm, Veterinary College, Bangalore May 2009.* & JN388657 \\
\hline \multicolumn{4}{|c|}{ Gujarat state } \\
\hline 2421 & Serum & Cow with fever from Animal Disease Investigation, Ramveri, Surat, Gujarat, September, 2006.* & JN388631• \\
\hline 2475 & Serum & $\begin{array}{l}\text { Following incidence of leptospirosis samples were collected from Deputy Director of Animal Husbandry, } \\
\text { Ambavadi, Ahmedabad, Gujarat, October, 2006.*- Cow, Gandhinagar }\end{array}$ & JN388635• \\
\hline 2757 & Serum & - Cow, Maninagar & JN388639 \\
\hline 2882 & Serum & - Cow, Amaraiwadi & JN388642 \\
\hline 2480 & Serum & - Cow, Raipur & JN388647• \\
\hline 2636 & Serum & - Dog, Ghatlodiya & JN388648 \\
\hline 2667 & Serum & - Dog, Khadiya & JN388649 \\
\hline 2713 & Serum & - Buffalo, NavaVadaj & JN388650 \\
\hline 2779 & Serum & - Cow, Maninagar & JN388651 \\
\hline 3334 & Serum & $\begin{array}{l}61 / 2 \text { years old HF cross breed cow with pyrexia from Veterinary dispensary, Badekhan Chakla. Kazimaidair, } \\
\text { Gopipur, Surat, Gujarat,August, 2007.* }\end{array}$ & JN388640 \\
\hline
\end{tabular}


Table 1 Details of characterized leptospira isolates from animals and humans (Continued)

\begin{tabular}{|c|c|c|c|}
\hline 3360 & Blood & $\begin{array}{l}\text { Following incidence of leptospirosis, cow samples were collected from Paldi village, Kakanj Tal Daskroi } \\
\text { District, Ahemadabad, Gujarat,September, 2007.* }\end{array}$ & JN388637 \\
\hline 3377 & Blood & $"$ & JN388653 \\
\hline \multicolumn{4}{|c|}{ Maharashtra state } \\
\hline 1215 & Serum & 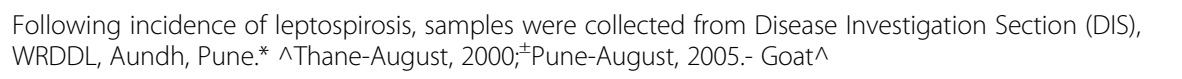 & HM046995 \\
\hline 1194 & Serum & $-\operatorname{Dog} \wedge$ & JN388615 \\
\hline 1856 & Serum & $-\operatorname{Cow}^{ \pm}$ & JN388632 \\
\hline 1756 & Serum & -Buffalo ${ }^{ \pm}$ & JN388625 \\
\hline 1761 & Serum & -Buffalo ${ }^{ \pm}$ & JN388630 \\
\hline 1762 & Serum/Blood & -Buffalo ${ }^{ \pm}$ & JN388618 \\
\hline 3395 & Serum & $\begin{array}{l}\text { Following incidence of leptospirosis, samples were collected from DIS, WRDDL, Pune, September 2007.*- } \\
\text { Goat, Rajapur }\end{array}$ & JN388638 \\
\hline 3394 & Serum & - Goat, Rajapur & JN388624 • \\
\hline 3398 & Serum & - Goat, Rajapur & JN388626• \\
\hline 3397 & Serum & - Goat, Pune & JN388641 \\
\hline \multicolumn{4}{|c|}{ Other states } \\
\hline 1183 & Blood & $\begin{array}{l}\text { Male elephant aged } 70 \text { years having fever from Department of Medicine, Veterinary college, Mannuthy } \\
\text { Kerala, June, 2000.* }\end{array}$ & HM046990 \\
\hline 1228 & Serum & $\begin{array}{l}4 \text { years old cow having pyrexia from District Medical office, Leptospira cell, Thodupuzha, Idukki. Kerala, } \\
\text { June, 2001.* }\end{array}$ & JN388619 \\
\hline 1256 & Serum & Dog with fever and Jaundice, Guwahati, Assam, July, 2001.* & HM046991• \\
\hline G70 & Blood/Serum & 3 years old repeat breeding cow, Goa, January 2006.\# & JN388617• \\
\hline G73 & Serum & 6 years old pregnant cow with pyrexia, Goa, January, 2006.\# & HM046996 \\
\hline G90 & Serum/Blood & Repeat breeding cow, Goa, September, 2006.\# & JN388623 \\
\hline
\end{tabular}

*Suspected samples received for leptospirosis diagnosis. \# Randomly collected samples for leptsospira study. Leptospira species identified • L.interrogans or L. borgpetersenii species, L.krischneri species, Leptospira intermediate species group.

especially kidney were rinsed thoroughly in media and teased the cortex and medulla region with sterile needle using media and suspension was prepared by mincing the specimen in pestle and mortar in biosafety cabinet and inoculated into culture medium containing 5-fluorouracil for isolation of leptospira organism and to prevent contamination of other bacteria. After incubation at $30^{\circ} \mathrm{C}$ in the laboratory for 4-5 days, the culture were filtered through $0.2 \mu \mathrm{m}$ membrane filter and subcultured periodically from 8 to 10 weeks. On successful isolation the cultures were stored in the semisolid EMJH medium for long-term storage as archived culture with periodical subculturing every 2 to 3 months for the viability of the organism.

In this study, 191 archived culture isolates from the samples that were collected from various hosts (Human-31; Cattle-82; Buffalo-11; Goat-11; Horse-8; Rat-25; Elephant-1; Dog-16 and water bodies-6), from different geographical locations of the country were taken for analysis to identify the isolated organisms initially as leptospira and further to characterize the pathogenic culture up to species level. These stored archived individual culture were revived again in liquid medium, for isolation of DNA for its molecular characterization along with the leptospira reference culture in liquid medium as the agarose present in the semi solid media will interfere in the pelleting of the leptospira organisms.

\section{Identification of the causative agent by PCR}

Genomic DNA was extracted from these cultures along with reference culture serovars using QIamp DNA mini kit (Qiagen, Germany) as per manufacturer's procedure. Initially, Leptospira genus-specific PCR was carried out using reported Lept 1 and Lept 2 primers as per method described by Merien et al. (1992) to differentiate the leptospira from other spirochetes. Then, $16 \mathrm{~S}$ rRNA gene-based PCR using E1 and E2 primers was performed which would amplify the $571 \mathrm{bp}$ amplicon from pathogenic leptospira (Faber et al. 2000). Then, $\sec Y$ gene (translocase)-based PCR was also employed using the G1 and G2 primer set, which would amplify the $285 \mathrm{bp}$ product from pathogenic Leptospira spp. (Gravekamp et al. 1993). Further, pathogenic isolates were characterized by rроB gene-specific PCR, which was carried out using reported $r p o B$ Lept $1,900 \mathrm{f}$ and $2,500 \mathrm{r}$ primers to amplify the partial gene sequences 
( $\approx 600$ bp product) for species identification (La Scola et al. 2006).

\section{Cloning, sequencing and phylogenetic analysis}

The $r p o B$ PCR amplicons were purified using QIA quick gel extraction Kit (Qiagen, Germany) as per manufacturer's protocol and cloned into pGEM-T Easy vector (Promega, USA) following standard molecular procedures using Top10F' E. coli host. The recombinant plasmid DNA was isolated and confirmed by PCR and restriction endonuclease analysis. The sequencing of plasmid was carried out commercially in an automated DNA sequencer. Nucleotide (nt) sequence analysis was performed with published rpoB gene sequences of other Leptospira spp. by using NCBI BLAST (Altschul et al. 1997). Further, comparative analysis of nt sequences were carried out by using the clustal W program alignment in MEGALIGN of Lasergene 6.0 (DNASTAR Inc., USA) package and sequence identity among all intermediate species was determined.

Phylogenetic tree was constructed based on partial nucleotide sequences of $r p o B$ gene by using Molecular Evolutionary Genetics Analysis (MEGA) version 4 (Tamura et al. 2007). The alignment gaps were excluded from pair wise distance estimations. The tree topologies were evaluated by using bootstrap test of phylogeny in the neighborjoining method and the bootstrap P-values were obtained after 1000 replicates of the dataset. The tree is drawn to scale, with branch lengths in the same units as those of the evolutionary distances used to infer the phylogenetic tree. The bootstrap consensus tree inferred from 1000 replicates was taken to represent the evolutionary history of the isolates analyzed. Branches corresponding to partitions reproduced in less than $50 \%$ bootstrap replicates were collapsed. The percentage of replicate trees in which the associated isolates clustered together in the bootstrap test were shown next to the branches. The evolutionary distances were computed using the Maximum Composite Likelihood (MCL) method and were in the units of the number of base substitutions per site. For comparison, available $r р о B$ gene sequences of Leptospira spp. were retrieved from GenBank, NCBI database for identifying the species of isolates, which clustered in to respective genenomospecies of the Leptospira genus.

\section{Results and discussion}

Several molecular techniques have been evaluated for the identification and characterization of Leptospira spp. and DNA-DNA hybridization identified 20 Leptospira species to date with nine pathogenic Leptospira species (Cerqueira and Picardeau 2009). This species assignment is consistent with the results of the phylogenetic analysis based on the rrs (16S) gene, which codes for the $16 \mathrm{~S}$ rRNA (Postic et al. 2000). La Scola et al. (2003) reported that analysis of a segment of $r p o B$ may be useful as an initial screening test for the identification of a new isolate of leptospira using a system of similarity cut-off to define species. This technique may be useful for the detection as well as identification of leptospira in clinical or environmental samples but not for serovar determination in L. interrogans species (La Scola et al. 2006).

In this study, out of 191 revived cultures, 99 were found positive in leptospira genus-specific PCR. The remaining 92 cultures may be other spirochete organisms namely Borrelia, Treponema, Leptonema, etc., as these organism looks like a spiral under dark field microscopy examination and staining (Gangadhar and Rajashekar 1998; Gangadhar et al., 2005). Of these 99 positive leptospira cultures, 52 isolates were identified as pathogenic, when tested by different type of PCR assays as described in materials and methods. These 52 isolates were further characterized by rроB gene-based nucleotide sequences and phylogenetic analyses, which revealed the prevalence of four Leptospira spp. $\{$ L. borgpetersenii or L. interrogans $(\mathrm{n}=30)$, L. kirschneri $(\mathrm{n}=8)$ and Leptospira intermediate species group $(\mathrm{n}=14)\}$ from animals and humans in India. Leptospira genus-specific PCR amplified 331bp products from the leptospira organism and different PCR assays detected 52 pathogenic organism, which also gave expected size of the PCR products from pathogenic isolates as described earlier. The remaining 47 culture isolates might be non pathogenic leptospira, which may require further study to classify these isolates using complete 16S rRNA sequencing. Further, rpoB genespecific amplicons were cloned into plasmid vector, characterized and sequenced. The characterized leptospira isolates were from different species (Human-10; Cattle-21; Buffalo-4; Goat-5; Rat-7; Elephant-1; Dog-4). The partial $r p o B$ gene sequences of the leptospira isolates were obtained (Table 1) after editing the primer sequences and submitted to the GenBank database (HM046989 to HM046997; JN388615 to JN388667).

By sequence analysis, the isolates showed identity with published sequences of various leptospires. L. interrogans was the most prevalent species among the examined samples of human and animals. In general, isolates belonging to either L. interrogans/L. borgpetersenii species showed 99 to $100 \%$ identity with reported sequences. Similarly, isolates belonging to L. kirschneri species had 98-99\% identity. However, isolates belonging to intermediate species showed only $77.9 \%$ to $78.3 \%$ and 78.1 to $78.5 \%$ identity with reported sequences of $L$. inadai and $L$. fainei species, respectively. La Scola et al. (2006) described the convention of identification in practice ie., if the partial rpoB similarity of a test isolate or strain is lower than $92 \%$, it should be regarded as a new species. If such a value goes above $97 \%$, then the isolate under scrutiny should be regarded as being representative of a known species. 


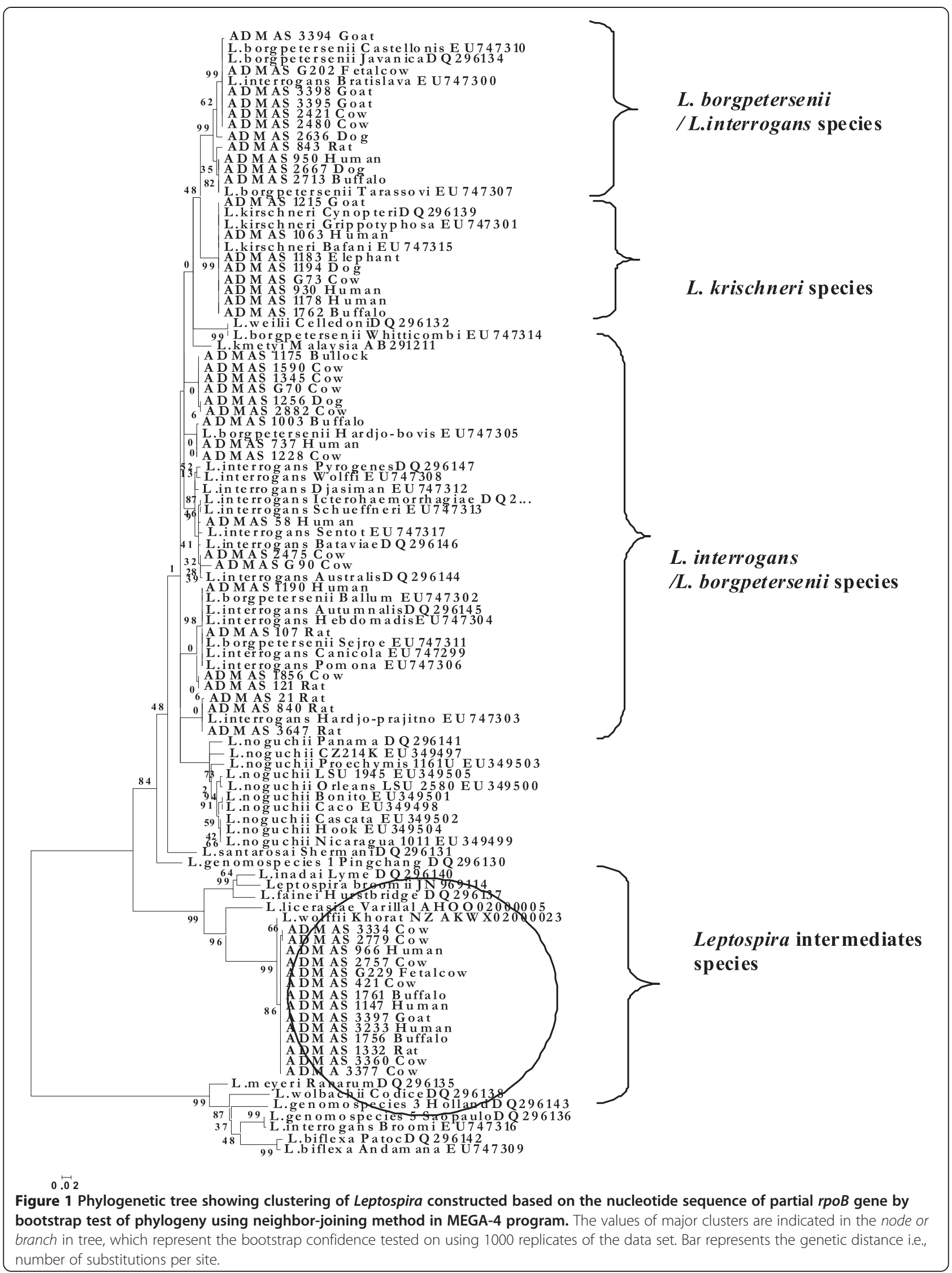


Surprisingly, 14 isolates belonging to intermediate species group showed identities from 99.1 to $99.6 \%$ with only one leptospira strain so far reported from Thailand $\{L$. wolffii serovar Khorat strain Khorat-H2 sequenceNZ_AKWX02000023\} (Slack et al., 2008). This molecular characterization indicates prevalence of the $L$. wolffii intermediate species in India. In India, earlier sporadic human case reports with $L$. inadai infection and circulation of $L$. inadai in reservoir hosts have been reported (Gangadhar et al., 2000; 2008).

Further, phylogenetic analysis (Figure 1) of 52 isolates based on $r p o B$ gene nucleotide sequences revealed that 30 isolates belong to either L. interrogans or L. borgpetersenii species and eight belongs to L. kirschneri species. However, clustering of 14 leptospira isolates branched into a separate group under intermediate species (namely L. wolffii species). Surprisingly, when analyzing in MEGALIGN, these isolates branch into a separate group under $L$. wolffii species and showed two to three different branching pattern within this group namely 8 isolates in one branch, 4 isolates in another and 2 isolates (ADMAS No. 2779 and 3334) in other separate branches. This may clearly indicate some of the isolates, which belong to particular serovars among this species. This is to be confirmed by further analysis using the referral panel of antigen and antibodies procuring from world reference laboratory.

Based on the present study, the major prevalent pathogenic species of Leptospira in animals and human were L. borgpetersenii / L. interrogans (30.3\%), intermediate species (14.14\%) and L. krischneri (8\%) in India. Similarly, in the bovine population, the percentage prevalence of aforementioned species among pathogenic isolates was $56 \%(14 / 25), 36 \%(9 / 25)$ and $8 \%(2 / 25)$, respectively. In Karnataka, the prevalence rate of these species among pathogenic isolates was found to be $62.25 \%(15 / 24)$, $25 \%(6 / 24)$ and $12.5 \%(3 / 24)$, respectively (Table 2$)$. The intermediate species requires further study to determine the exact serovars or new species, as recently more classification of new isolates was made for this intermediate species (Levett et al. 2006; Matthias et al. 2008). Similarly, $L$. wolffii, a potential pathogenic leptospira species detected in human, sheep and dog as intermediate species (Slack et al., 2008; Zakeri et. al., 2010a,b). The presence of $L$. wolffii with $100 \%$ identity in clinical human samples and animals suspected with leptospira may provide evidence for circulation of $L$. wolffii and its role in transmission cycle within human and animal hosts in Iran (Zakeri et. al., 2010a). To establish the possible seroprevalence of this species in the population, the inclusion of intermediate species serovars representative of all the serogroups in the panel of leptospira cultural serovars besides regular serovars used in MAT for seroepidemiological studies in animals and humans as recommended earlier (Gangadhar et al. 2000).

To the best of our knowledge, this is the first study to use $r p o B$ gene-based phylogenetic analysis to identify or detect Leptospira intermediate species in animals and humans in India. Isolation and characterization of leptospires from the samples collected from different hosts, clearly suggested a possible leptospiral infection / or carrier status. Isolation of leptospires from blood

Table $\mathbf{2}$ Characterized Leptospira species from animals and humans in different states of India

\begin{tabular}{|c|c|c|c|c|c|}
\hline State & Species & L. borgpetersenii or L. interrogans species & Leptospira intermediate species & L. krischneri species & Total \\
\hline \multirow[t]{4}{*}{ Karnataka } & Cattle & 4 & 2 & - & 6 \\
\hline & Buffalo & 1 & - & - & 1 \\
\hline & Human & 4 & 3 & 3 & 10 \\
\hline & Rodents & 6 & 1 & - & 7 \\
\hline \multirow[t]{3}{*}{ Gujarat } & Cattle & 4 & 5 & - & 9 \\
\hline & Buffalo & 1 & - & - & 1 \\
\hline & Dog & 2 & - & - & 2 \\
\hline \multirow[t]{4}{*}{ Maharashtra } & Cattle & 1 & - & - & 1 \\
\hline & Buffalo & - & 2 & 1 & 3 \\
\hline & Dog & - & - & 1 & 1 \\
\hline & Goat & 3 & 1 & 1 & 5 \\
\hline Goa & Cattle & 2 & - & 1 & 3 \\
\hline \multirow[t]{2}{*}{ Kerala } & Elephant & - & - & 1 & 1 \\
\hline & Cattle & 1 & - & - & 1 \\
\hline \multirow[t]{2}{*}{ Assam } & Dog & 1 & - & - & 1 \\
\hline & Total & 30 & 14 & 8 & 52 \\
\hline
\end{tabular}


samples of cows with either history of abortions or reproductive disorders does not necessarily incriminate leptospira as the etiology of the disorder but only serve as a possible indicator to the existence of the infection. Role of leptospira infection in abortions and reproductive disorders is well established by earlier workers including our earlier studies (Ellis et al. 1976; Poonacha et al. 1993; Gangadhar et al. 2008). Infected cattle are known to be maintenance host resulting in illness leading to abortion, stillbirth, infertility and mastitis or clinically normal but harbour infection and act as a potential source of infection (Higgins et al. 1980)

Leptospira and its maintenance hosts appear to undergo adaptation to their environment, and the preference and pathogenicity of these hosts can change with time and geographic region. Transmission of the infection among maintenance hosts (which remains largely asymptomatic) is efficient and the incidence of infection in humans are relatively high as they are incidental hosts or accidental hosts (which develop clinical disease). Because of the wide spectrum of animal species that serve as reservoirs/maintenance hosts, leptospirosis is considered as the most widely spread zoonotic disease.

The significance of intermediate species in public health and animal reproduction is neither clearly understood nor documented much in literature. It is imperative to identify the species prevalence as well as to know the pathogenic nature and its virulence factors, drug resistance etc. In order to understand the newly emerging leptospira in animals and humans by employing various techniques and to combat the problem associated with the disease conditions. Further studies should be carried out on characterization, identification by pulse field gel electrophoresis and hybridization techniques and pathological studies using hamster model in order to identify the exact Leptospira species.

The disease is of public health importance and warrants bio-safety measures in handling the organism and/or disease. Prevalence of intermediate species identified, will surely emphasize the importance of consideration of this species in India for further studies especially to understand the newly emerging leptospira in animals and humans and to combat the problem associated with the disease conditions if any. Therefore, it is important to increase attention about this disease among physicians and to strengthen laboratory capacity for its diagnosis. However, systematic random screening of the samples from different animals and at-risk personnel is required to know the exact prevalence rate in particular geographical locality, which again depends on the various epidemiological factors influencing leptospirosis occurrence and its spread. This could be useful in the selection of panel of serovars to be used in the MAT at different geographical location to provide proper diagnosis in animals and humans, which in turn will lead to development of specific diagnostics and also to determine the exact prevalence of leptospirosis in different species. Further, a large systematic epidemiology survey would be needed to define the presence and the prevalence of this pathogenic intermediate species in endemic regions of India.

\section{Competing interests}

The authors declares that they have no competing interests.

\section{Authors' contributions}

VB and NM-conceptualized and planned the study. VB designed and performed the work, molecular genetic studies, participated in the sequence alignment and drafted the manuscript. NLG -samples collection, isolation and revival of culture isolates of leptospira. SRAT and MD- PCR amplification and cloning of the $r P O B$ gene sequences from revived culture isolates. RS and PK-cataloguing and revival of culture isolates of leptospira. KP and HR guided the research throughout the study and arranged facility to complete this work. VB and NM wrote and revised the paper and approved the submission of the manuscript. All authors read and approved the final manuscript.

\section{Acknowledgements}

Authors wish to thank Deputy Director General (Animal Sciences) and Assistant Director General (Animal Health), Indian Council of Agricultural Research (ICAR), New Delhi, India, for financial support and encouragement. The authors also thank the Directors of the state Animal Husbandry Departments and human hospitals for sending the samples to the PD_ADMAS for providing diagnosis of leptopsirosis. The authors also thank Dr. P.Vijayachari, Director, Regional Medical Research Centre (ICMR), Port Blair, for providing the leptospira reference cultures and also for his constant support and encouragement.

Received: 15 May 2013 Accepted: 29 July 2013

Published: 30 July 2013

\section{References}

Altschul SF, Madden TL, AA S a, Zhang J, Zhang Z, Miller W, Lipman DJ (1997) Gapped BLAST and PSI-BLAST: a new generation of protein database search programs. Nucleic Acids Res 25:3389-3402

Bharti AR, Nally JE, Ricaldi JN, Matthias MA, Diaz MM, Lovett MA, Levett PN, Gilman RH, Willig MR, Gotuzzo E, Vinetz JM (2003) Leptospirosis: a zoonotic disease of global importance. Lancet Infect Dis 3(12):757-771

Cerqueira GM, Picardeau M (2009) A century of Leptospira strain typing. Infect Genet Evol 9:760-768

Cerqueira GM, McBride AJA, Picardeau M, Ribeiro SG, Morel V, Reis MG, Ko Al, Dellagostin OA (2009) Distribution of the Leptospiral immunoglobulinlike (Lig) genes in pathogenic Leptospira spp. and application of ligB to typing leptospiral isolates. J Med Microbiol 58:1173-1181

Ellis WA (1986) The present status of leptospirosis diagnosis and control. In: Ellis WA, Little WA (ed) The diagnosis of Leptospirosis in farm animals. Martinous Nijhoff publishers, The Netherlands, pp 13-31

Ellis WA, Obrien JJ, Neill S, Henna J, Bryson DG (1976) The isolation of a Leptospira from an aborted fetus. Vet Rec 99:458-459

Faber NA, Crawford M, LeFebvre RB, Buyukmihci NC, Madigan JE, Willits NH (2000) Detection of Leptospira spp. in the aqueous humor of horses with naturally acquired recurrent uveitis. J Clinic Microbiol 38(7):2731-2733

Gangadhar NL, Rajasekhar M, Smythe LD, Norris MA, Symonds ML, Dohnt MF (2000) Reservoir hosts of Leptospira inadai in India. Rev Sci Tech OIE 19(3):793-799

Gangadhar NL, Rajashekar M (1998) A modified silver impregnation staining for Leptospira. Indian Vet J 75:349-351

Gangadhar NL, Prabhudas K, Bhushan S, Sulthana M, Barbuddhe SB, Rhaman H (2008) Leptospira infection in animals and humans: a potential public health risk in India. Rev Sci Tech OIE 27(3):885-892

Gangadhar NL, Prabhudas K, Gajendragad MR, Shashibhushan J, Kakoli A (2006) Leptospirosis: an enigma of Zoonosis for the developing world. Infect Dis J Pakistan 15(10):20-24

Gangadhar NL, Rajasekhar M, Prabhudas K (2005) Isolation of Leptonema from rodents and cattle in India. Indian J Anim Science 75(5):508-510 
Gravekamp C, Van de Kemp H, Franzen M, Carrington D, Schoone GJ, Van Eys GJ, Everard CO, Hartskeerl RA, Terpstra WJ (1993) Detection of seven species of pathogenic leptospires by PCR using two sets of primers. J Gen Microbiol 139:1691-1700

Hartskeerl RA, Goris MG, Brem S, Meyer P, Kopp H, Gerhards H, Wollanke B (2004) Classification of leptospira from the eyes of horses suffering from recurrent uveitis. J Vet Med B 51:110-115

Higgins RJ, Harbourne JF, Little TWA, Stevens AE (1980) Mastitis and abortion in dairy cattle associated with Leptospira of the serotype hardjo. Vet Rec 27:307-310

La Scola B, Bui LT, Baranton G, Khamis A, Raoult D (2006) Partial rpoB gene sequencing for identification of Leptospira species. FEMS Microbiol Lett 263(2):142-147

La Scola B, Zeaiter Z, Khamis A, Raoult D (2003) Gene-sequence-based criteria for species definition in bacteriology: the Bartonella paradigm. Trends Microbiol 11(7):318-321

Levett PN (2001) Leptospirosis. Clinic Microbiol Rev 14:296-326

Levett PN, Morey RE, Galloway RL, Steigerwalt AG (2006) Leptospira broomii sp. nov., isolated from humans with leptospirosis. Int J Syst Evol Microbiol 56(3):671-673

Matthias MA, Ricaldi JN, Cespedes M, Diaz MM, Galloway RL, Saito M, Steigerwalt AG, Patra KP, Ore CV, Gotuzzo E, Gilman RH, Levett PN, Vinetz JM (2008) Human leptospirosis caused by a new, antigenically unique Leptospira associated with a Rattus species reservoir in the Peruvian Amazon. PLoS Negligible Tropical Dis 2(4):1-12

Merien F, Amouriauz P, Perolat P, Baranton G, Saint Girons I (1992) Polymerase chain reaction for detection of Leptospira spp. in clinical samples. J Clinic Microbiol 30:2219-2224

Paster BJ, Dewhirst FE, Weisburg WG, Tordoff LA, Fraser GJ, Hespell RB, Stanton TB, Zablen L, Mandelco L, Woese CR (1991) Phylogenetic analysis of the spirochetes. J Bacteriol 173:6101-6109

Poonacha KB, Donahue JM, Giles RC, Hong CB, Petrites-murphy MB, Smith BJ, Swerczek TW, Tramont RR, Tuttle PA (1993) Leptospires in equine fetuses, stillborn foals and placentas. Vet Pathol 30(4):362-369

Postic D, Riquelme-Sertour N, Merien F, Perolat P, Baranton G (2000) Interest of partial $165 \mathrm{rDNA}$ gene sequences to resolve heterogeneities between Leptospira collections: application to L. meyeri. Res Microbiol 151(5):333-341

Slack AT, Kalambaheti T, Symonds ML, Dohnt MF, Galloway RL, Steigerwalt AG, Chaicumpa W, Bunyaraksyotin G, Craig S, Harrower BJ, Smythe LD (2008) Leptospira wolffii sp. nov., isolated from a human with suspected leptospirosis in Thailand. Int J System Evol Microbiol 58:2305-2308

Slack AT, Symonds ML, Dohnt MF, Smythe LD (2006) Identification of pathogenic Leptospira species by conventional or real-time PCR and sequencing of the DNA gyrase subunit $B$ encoding gene. BMC Microbiol 6:95

Steinen ACM, Schuurman JL, Gravekamp C, Korver H, Terpstra WJ (1992) Muskrats as carriers of pathogenic leptospires in The Netherlands. Anton Van Leeuwonhook 61:43-50

Tamura K, Dudley J, Nei M, Kumar S (2007) Molecular Evolutionary Genetics Analysis (MEGA) software version 4.0. Mol Biol Evol 24:1596-1599

Terpstra WJ, Korver H, Van Leeuwen J, Klatser PR, Kolk AHJ (1985) The classification of Sejroe group serovars of Leptospira interrogans with monoclonal antibodies. Zentralbl Bakteriol Mikrobiol Hygiene 259:498-506

Zakeri S, Khorami N, Ganji ZF, Sepahian N, Malmasi AA, Gouya MM, Djadid ND (2010a) Leptospira wolffii, a potential new pathogenic Leptospira species detected in human, sheep and dog. Infect Genet Evol 10(2):273-277

Zakeri S, Sepahian N, Afsharpad M, Esfandiari B, Ziapour P, Djadid ND (2010b) Molecular epidemiology of leptospirosis in northern Iran by nested polymerase chain reaction/restriction fragment length polymorphism and sequencing methods. American J Trop Med Hyg 82(5):899-903

doi:10.1186/2193-1801-2-362

Cite this article as: Balamurugan et al:: Characterization of leptospira isolates from animals and humans: phylogenetic analysis identifies the prevalence of intermediate species in India. SpringerPlus 2013 2:362.

\section{Submit your manuscript to a SpringerOpen ${ }^{\odot}$ journal and benefit from:}

- Convenient online submission

- Rigorous peer review

- Immediate publication on acceptance

- Open access: articles freely available online

- High visibility within the field

- Retaining the copyright to your article

Submit your next manuscript at $\gg$ springeropen.com 